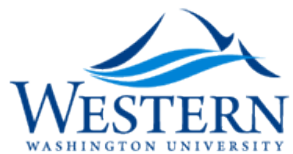

Western Washington University

Western CEDAR

\title{
Archives for All: Professional Responsibility and Social Justice
}

Randall C. Jimerson Western Washington University

Western Washington University, randall.jimerson@wwu.edu

Follow this and additional works at: https://cedar.wwu.edu/history_facpubs

Part of the Archival Science Commons

\section{Recommended Citation}

Jimerson, Randall C. Western Washington University, "Archives for All: Professional Responsibility and Social Justice" (2007). History Faculty and Staff Publications. 66.

https://cedar.wwu.edu/history_facpubs/66 
Archives for All: Professional Responsibility and Social Justice

Author(s): Randall C. Jimerson

Source: The American Archivist, Vol. 70, No. 2 (Fall - Winter, 2007), pp. 252-281

Published by: Society of American Archivists

Stable URL: http://www.jstor.org/stable/40294571

Accessed: 01-10-2015 15:10 UTC

\section{REFERENCES}

Linked references are available on JSTOR for this article:

http://www.jstor.org/stable/40294571 ?seq=1\&cid=pdf-reference\#references_tab_contents

You may need to $\log$ in to JSTOR to access the linked references.

Your use of the JSTOR archive indicates your acceptance of the Terms \& Conditions of Use, available at http://www.jstor.org/page/ info/about/policies/terms.jsp

JSTOR is a not-for-profit service that helps scholars, researchers, and students discover, use, and build upon a wide range of content in a trusted digital archive. We use information technology and tools to increase productivity and facilitate new forms of scholarship. For more information about JSTOR, please contact support@jstor.org. 


\title{
Archives for All: Professional Responsibility and Social Justice
}

\author{
Randall C. Jimerson
}

\begin{abstract}
A bstract
Archivists should use their power-in determining what records will be preserved for future generations and in interpreting this documentation for researchers-for the benefit of all members of society. By adopting a social conscience for the profession, they can commit themselves to active engagement in the public arena. Archivists can use the power of archives to promote accountability, open government, diversity, and social justice. In doing so, it is essential to distinguish objectivity from neutrality. Advocacy and activism can address social issues without abandoning professional standards of fairness, honesty, detachment, and transparency.
\end{abstract}

\section{Prologue}

Before discussing an issue as politically charged as the one undertaken here, it is only proper that I provide the context of my own personal experience from which this arises. I do so not to claim a privileged position on such concerns, which could affect the foundations of my professional identity as an archivist, but to clarify my own perspective so that the reader can judge it for what it is.

My first encounters with archives came as a graduate student at the University of Michigan, conducting research on sectional identity as seen through the voices of common people during the Civil War. While writing my $\mathrm{PhD}$ dissertation on this topic, I took a half-time position as graduate assistant at the Bentley Historical Library. This led to a full-time grant position at Michigan and then to two years as a manuscripts processor at Yale University. As the first archivist hired at the University of Connecticut, I spent fifteen years developing a university archives and records management program, soliciting manuscript collections relating to state

This is a revised and expanded version of a paper presented at the August 2006 annual meeting of the Society of American Archivists under the title "Using the Power of Archives for a Better Society," session 107, "The Archival Pharmakon." The session, and this paper in particular, were designed as responses to the author's 2005 SAA presidential address, "Embracing the Power of Archives," published in American Archivist 69 (Spring/Summer 2006): 19-32. 
A R C H I V E S F O R A L L : P R O F E S S I O N N A L R R E S P O

history, and performing or supervising arrangement, description, preservation, reference, and outreach functions. I was able to fill gaps in the archival record by acquiring labor union records, papers of political activists, and records of ethnic and African-American groups and individuals.

One of the most memorable experiences I had, however, came when a sixtyfive-year-old woman requested a copy of her City of Hartford voter registration record, which we had acquired when the state retention requirement expired, to begin collecting Social Security. Because of our archival records she could obtain her retirement checks. I thus learned that archives are more than repositories of historical resources. They also protect the rights and benefits of all citizens-even the poorest and most needy.

When anyone asks me why I am an archivist, these are the stories I want to tell. Sometimes I settle for the shorthand of saying that I want to help preserve the past so we will know our social heritage. Sometimes I refer to the rights of citizens, or the necessity of keeping public officials accountable for their actions. But underlying these general platitudes are the stories from my own experience.

My father dedicated his life to public service-as a prison chaplain in Virginia, a civil rights activist in Alabama, a community welfare director in Elmira, New York, and codirector of a peace center in Roanoke, Virginia. After putting aside a career in architecture to raise five children, my mother later codirected the Roanoke peace center and then worked on Capitol Hill as a congressional liaison for the Church of the Brethren. My four brothers and sisters have all worked in public service positions, including in the Peace Corps in Honduras, in AIDS education in developing countries, in social work helping halfway house residents, in school administration serving young children in Haiti, in mental health work, and in social work to help teenaged fathers.

Coming from such a family, I have sometimes had to search for the public service elements of my chosen profession. I have found that archivists can make important contributions to society: some people receive retirement benefits because of our work preserving public records; others discover links to their family's past; researchers understand more clearly how their home communities developed; and public officials may think twice before violating the public trust because of what archivists do.

Archivists can thus contribute to a richer human experience of understanding and compassion. They can help to protect the rights of citizens and to hold public figures in government and business accountable for their actions. They can provide resources for people to examine the past, to comprehend the present, and to prepare for a better future. This is the essence of our common humanity. It provides archivists with a sense of professional purpose and a social conscience. 
Archivists have only recently begun to re-examine their assumptions about the neutrality and objectivity of archives. In the "information age," knowledge is power. This power gives those who determine what records will be preserved for future generations a significant degree of influence. Archivists must embrace this power, rather than continuing to deny its existence. ${ }^{1}$

In addition to protecting the rights and interests of all citizens, archives preserve vital aspects of cultural heritage. These dual responsibilities give archivists significant power, not only over questions of recordkeeping in today's society but for future generations. Such power carries an obligation to employ it for positive purposes, as archivists search for a role to play for the benefit of all people in society.

In looking at the history of archives since ancient times and how they have been used to bolster the prestige and influence of the powerful elites in societies, I contend that archivists have a moral professional responsibility to balance that support given to the status quo by giving equal voice to those groups that too often have been marginalized and silenced. We can see many precedents for this professional imperative. Examples of the use of records and archives to redress social wrongs and support the causes of justice and community consciousness among marginalized groups are growing more numerous. Archivists can become active agents for change, in accordance with their existing professional principles, by taking active steps to counter the biases of previous archival practices.

Historical examples abound of societies in which the powerful ruled by controlling and manipulating information and records. From ancient times to the present, disquieting use has been made of archival records to establish, document, and perpetuate the influence of power elites. Noam Chomsky observes that "elites depend on sophisticated information systems, media control, surveillance," and related measures to maintain their positions. ${ }^{2}$ Jacques Derrida explicitly links political power to the archives: "There is no political power without control of the archive, if not of memory."

We see this in modern times with the widely recognized proficiency of Nazi recordkeeping, ${ }^{4}$ the use of official records to bolster the apartheid regime in

\footnotetext{
${ }^{1}$ I explored this theme in my presidential address to the Society of American Archivists in 2005, which serves as the starting point for the present article. See Jimerson, "Embracing the Power of Archives," 19-32.

${ }^{2}$ Chomsky as paraphrased by Verne Harris, "Archives, Politics, and Justice," in Political Pressure and the Archival Record, ed. Margaret Procter, Michael Cook, and Caroline Williams (Chicago: Society of American Archivists, 2005), 175.

${ }^{3}$ Jacques Derrida, Archive Fever: A Freudian Impression (Chicago: University of Chicago Press, 1996), 4.

${ }^{4}$ Ernst Posner, "The Role of Records in German Administration," in Archives and the Public Interest: Selected Essays by Ernst Posner, ed. Ken Munden (Washington, D.C.: Public Affairs Press, 1967), 87-97.
} 
South Africa, ${ }^{5}$ and documentation of the Cambodian genocide under Pol Pot. When the Khmer Rouge were evacuating Phnom Penh ahead of the Vietnamese in January 1979, they gave orders to the prison chief to destroy all the records of the secret prison, of which the outside world knew nothing. However, according to Ben Kiernan of the Yale University Genocide Studies Program, "he preferred to kill the last surviving prisoners instead, in the couple of hours of time that he had before the Vietnamese arrived at the prison. When they did get there, they found 100,000 pages of archives of the prison-execution schedules, daily record of torture of prisoners and their forced confessions." Kiernan adds that the "archives of the Khmer Rouge prison system across the country, showing high-level involvement and the implication of the top leaders of the Khmer Rouge in the crimes that were committed" made it impossible for them to deny their genocidal crimes. ${ }^{6}$ This is but one example of how archival records can overcome efforts to deny the past.

Even in democratic societies, public officials often seek to control public discourse by manipulating access to information, as Tim Ericson clearly and eloquently reminded us in his 2004 Society of American Archivists presidential address: "Nothing has been able to slow the growth of secrecy in government. Many suspect it serves the interests of politics, malfeasance, misdeeds, and potential embarrassment more than our national security." Government secrecy is the enemy of truth, accountability, and social justice.

\section{Archives and Records for the Public Interest}

Despite these unpleasant truths - or more accurately, because of them-I remain optimistic that archivists can become agents of change in the interests of accountability, social justice, and diversity. If we do not seize this opportunity, in the words of Jerry Ham a generation ago, ". . . then I do not know what it is we are doing that is all that important." 8

\footnotetext{
${ }^{5}$ Verne Harris, "Redefining Archives in South Africa: Public Archives and Society in Transition, 1990-1996," in Archives and Justice: A South African Perspective (Chicago: Society of American Archivists, 2007), 173-202.

${ }^{6}$ Ben Kiernan, Yale Center for International and Area Studies Global Resources Network Conference, March 2005, available at http://www.library.yale.edu/mssa/globalrecord/new_web/kiernan_ richie.html\#text, accessed 6 July 2007. See also Dawne Adam, "The Tuol Seng Archives and the Cambodian Genocide," Archivaria 45 (Spring 1998): 5-26.

${ }^{7}$ Timothy L. Ericson, "Building Our Own 'Iron Curtain': The Emergence of Secrecy in American Government," American Archivist 68 (Spring/Summer 2005): 50.

${ }^{8}$ F. Gerald Ham, "The Archival Edge," in A Modern Archives Reader, ed. Maygene Daniels and Timothy Walch (Washington, D.C.: National Archives and Records Service, 1984), 335.
} 
What gives me hope are recent events in which archives and records have contributed to the public interest in four ways:

1. by holding political and social leaders accountable for their actions,

2. by resisting political pressure in order to support open government,

3. by redressing social injustices, and

4. by documenting underrepresented social groups and fostering ethnic and community identities.

This evidence comes from many sources, but in particular from three recent volumes: Archives and the Public Good: Accountability and Records in Modern Society, edited by Richard Cox and David Wallace; Political Pressure and the Archival Record, edited by Margaret Procter, Michael Cook, and Caroline Williams; and Archives and Justice: A South African Perspective, by Verne Harris. ${ }^{9}$ These accounts help us to understand how records and archives can be used as resources to counter injustice and abuses of power, and to develop a strategy for using the power of archives.

Accountability

The Watergate crisis in the mid-1970s focused public attention on the importance of records in discovering political crimes and holding public figures accountable for their actions. Only with the "smoking gun" of the secret tape recordings of Oval Office conversations could the true story of the Nixon administration's obstruction of justice be proven. This led directly to the House of Representatives' impeachment proceedings and the president's resignation. In response to Nixon's abuses of power, Congress passed the Presidential Records and Materials Act (1974) and other legislation to establish the principle of public ownership and access to presidential records. Control over presidential records surfaced again with the PROFS case, which revealed an attempt by the officials of the George H. W. Bush administration to destroy computer tapes, including electronic mail (on the PROFS software system) containing explosive revelations of illegal activities of the Reagan-Bush administrations regarding the Iran-Contra affair; investigations of Panama's leader Manuel Noriega; and billions of dollars loaned to Iraq before the first Gulf War. "What the Nixon and the PROFS case[s] demonstrate is that the archival community, and indeed all its allied professions, must be ever vigilant in helping to ensure that American citizens have all the requisite information to make informed decisions regarding the activities of their government," Bruce Montgomery concludes. "Archivists

\footnotetext{
${ }^{9}$ Richard J. Cox and David A. Wallace, eds., Archives and the Public Good: Accountability and Records in Modern Society (Westport, Conn.: Quorum Books, 2002); Procter, Cook, and Williams, Political Pressure and the Archival Record; and Harris, Archives and Justice.
} 
have always played an important, albeit obscure, role in the enterprise of promoting the public's right to know. But this role is also contingent on the need to speak out on issues of vital historical concern." 10 The importance of Nixon's presidential papers can be seen in the protracted legal struggle to control their disposition and accessibility. This struggle lasted long after Nixon's death.

In the 1980s, the Iran-Contra scandal itself showed that, although Oliver North and other Reagan administration officials destroyed documents relating to their illegal activities, some records (including email backup tapes) remained to prove their guilt. The Tower Commission, which investigated the Iran-Contra charges, concluded that the "whole matter was handled too informally, without adequate written records of what had been considered, discussed, and decided." According to the Tower Commission Report, adequate records of decisions would be "essential for conducting a periodic review of a policy or initiative, and to learn from the past." 11 Not only did North and National Security Advisor John Poindexter destroy critical records of illegal activities, they also engaged in "creating a false history of events" to cover up their actions. ${ }^{12}$

Despite their zealous efforts to destroy and alter records, North and Poindexter overlooked crucial backup tapes, which allowed investigators to recover emails that provided a "first-hand contemporaneous account of events." ${ }^{13}$ Independent Counsel Lawrence Walsh concluded that the central participants in this scandal "were reluctant to provide truthful information unless they were confronted with difficult-to-refute documentary evidence." 14 As David Wallace concludes, "aggressive oversight and power to seize the documentary record provides one of the few means by which democratic accountability can be secured in a national security context." Since government officials could not be trusted to tell the truth, Wallace adds, "only by having the power to seize and have unimpeded access to the documentary record will investigations have any hope of yielding an accurate accounting of events." ${ }^{15}$ Records thus provide an essential measure of accountability. Even with extensive efforts to alter and destroy such records, the Iran-Contra conspirators could not escape such evidence. To ensure accountability, it is critical to establish clear recordkeeping requirements, to protect important records from destruction, and to understand and value proper recordkeeping practices.

${ }^{10}$ Bruce P. Montgomery, "Nixon's Legal Legacy: White House Papers and the Constitution," American Archivist 56 (Fall 1993): 609.

${ }^{11}$ David A. Wallace, "Implausible Deniability: The Politics of Documents in the Iran-Contra Affair and Its Investigations," in Archives and the Public Good, 95-96.

${ }^{12}$ Wallace, "Implausible Deniability," in Archives and the Public Good, 99.

${ }^{13}$ Wallace, "Implausible Deniability," in Archives and the Public Good, 106.

${ }^{14}$ Wallace, "Implausible Deniability," in Archives and the Public Good, 108.

${ }^{15}$ Wallace, "Implausible Deniability," in Archives and the Public Good, 112. 
In Australia, the Heiner affair of the 1990s demonstrated the possibility of co-opting records managers and archivists to cover up governmental misdeeds under the guise of records disposition. To prevent public airing of charges of physical and sexual abuse in Queensland's institutions for teenagers and children, government leaders ordered the destruction of all records of the investigation led by Noel Heiner. Although this violated records policies, the cabinet secured consent from the state's archivist in carrying out this records destruction. The argument made was that the archivist should only consider the records' value for historical research. However, as Chris Hurley argues, "Of more significance is the role of an independent archives authority in preventing the untoward destruction of evidence of government corruption and wrongdoing by establishing a regime of records management that supports the public interest in government accountability." Hurley concludes, the "value added" by archives is "that agencies must submit their records practices to external scrutiny. This provides additional safeguard for the public interest in records retention (to ensure that governments cannot 'cover up') and a safeguard too for individual citizens in conflict with government." 16

The Heiner affair showed both the power of records to document abuses and-as in the Iran-Contra scandal-the incentive that government leaders sometimes have to destroy public records. For an archivist or records manager to comply with improper requests to approve document destruction is a clear violation of professional ethics. The SAA Code of Ethics, for example, states: "Archivists strive to promote open and equitable access to their services and the records in their care without discrimination or preferential treatment, and in accordance with legal requirements, cultural sensitivities, and institutional policies." 17 However, the fact that government leaders felt the need to obtain such archival authorization demonstrates that archivists have power to protect the public interest, when they uphold their obligations.

The Enron/Arthur Anderson scandal, exposed in 2001, demonstrated that the legal system can, at times, intervene to ensure that records cannot be destroyed or altered without consequences. As concerns mounted about Enron's financial future, auditors at Arthur Anderson received a memo directing them to destroy all but routine auditing records relating to Enron. As Time magazine reported in January 2002:

Any deliberate destruction of documents subject to subpoena is illegal. In Arthur Anderson's dealings with the documents related to Enron, "the mind-set seemed to be, if not required to keep it, then get rid of it," says Ken

\footnotetext{
${ }^{16}$ Chris Hurley, "Records and the Public Interest: The 'Heiner Affair' in Queensland, Australia," in Archives and the Public Good, 313.

${ }^{17}$ Society of American Archivists, Code of Ethics, available at http://www.archivists.org/governance/ handbook/app_ethics.asp, accessed 1 December 2006.
} 
Johnson, spokesman for the House Energy and Commerce Committee... . "Anyone who destroyed records out of stupidity should be fired," said committee chairman Billy Tauzin, a Louisiana Republican. "Anyone who destroyed records to try to circumvent our investigation should be prosecuted."18

This scandal is a cautionary tale of corporate power run amok and of the dangers of improper management of records. Yet it also shows that with regulation, such as the Sarbanes-Oxley law passed as a result of such abuses, it is possible to assert professional standards of records management and archives. ${ }^{19}$

Open Government

The necessity of professional archival control over records becomes especially clear when considering the importance of public access to governmental records. The French Revolution established the principle of public control of records to prevent governmental abuses and to protect the rights of citizens. ${ }^{20}$ Concern for public access to records, essential for trust and accountability, stems from the long history of government leaders' efforts to use the interpretation of the past to secure their power. In his essay "Why Do Ruling Classes Fear History?" historical sociologist Harvey Kaye quotes J. H. Plumb, who wrote that from ancient to recent times, "The past was constantly involved in the present, and all that enshrined the past-monuments, inscriptions, records-were essential weapons in government, in securing the authority, not only of the king, but also of those whose power he symbolized and sanctified." Kaye also notes that Soviet leader Nikita Khrushchev recognized the power of historical knowledge, when he stated, "Historians are dangerous people, capable of turning everything topsy-turvy. They have to be watched." ${ }^{21}$ Given this Soviet suspicion of history, it may seem surprising that the former Communist countries have opened their Cold War archives more quickly than Western nations. "Whereas the archives have been opened in Berlin and Moscow, American and other Western secrets about state and corporate crimes committed under license of the Cold

\footnotetext{
18 "Who's Accountable? Inside the Growing Enron Scandal: How Evidence Was Shredded and Top Executives Fished for a Bailout as the Company Imploded," Time, 13 January 2002, available at http://www.commondreams.org/cgi-bin/print.cgi?file=/headlines02/0113-02.htm, accessed 12 May 2007.

${ }^{19}$ Patrice Davis, "Some Much Deserved Respect: The Impact of the Sarbanes-Oxley Act from a Records Management Perspective Focusing on Small Businesses" (master's thesis, Western Washington University, 2006), 62-65.

${ }^{20}$ Ernst Posner, "Some Aspects of Archival Development Since the French Revolution," in Archives and the Public Interest, 23-35; Judith M. Panitch, "Liberty, Equality, Posterity?: Some Archival Lessons from the Case of the French Revolution," American Archivist 59 (Winter 1996): 30-47.

${ }^{21}$ Harvey J. Kaye, "Why Do Ruling Classes Fear History?" and Other Questions (New York: St. Martin's Griffin, 1997), 14-15.
} 
War are only beginning to seep out," Kaye wrote in 1994. He cited a former U.S. official's estimate that "possibly, one-third of American history is classified."22 This control over information affects both totalitarian and democratic governments. Kaye argued that ruling classes fear history because they recognize "that history has been, and remains, a process of struggle for freedom and for justice." ${ }^{23}$ Historical understanding, particularly when embedded in the records of social institutions and individuals, makes both history and archives dangerous to those seeking to maintain their political power.

The George W. Bush administration is not the first democratic government to limit public access to information and records of its activities, although its policies have drastically reduced such access. In 2001, Bruce Shapiro of the Nation magazine, denounced the administration's policies as "information lockdown." He cited the Justice Department's refusal to release the names of individuals jailed as suspected terrorists; Attorney General John Ashcroft's memorandum authorizing federal agencies to deny Freedom of Information Act requests; and the removal of certain information from agency websites, on the claim of national security. ${ }^{24}$ As archivist Thomas Connors observed, "This push toward ever greater control of information access is seen by many as a threat to the democratic political process and to open government." ${ }^{25}$ In response to Executive Order 13233, which removed power to grant access to presidential records from the Archivist of the United States and claimed such power for the Executive Office of the President, SAA president Steve Hensen asked, "How can a democratic people have confidence in elected officials who hide the record of their actions from public view? . . Access to the vital historical records of this nation should not be governed by executive will; this is exactly the situation that the existing law was created to prevent." 26

In all democratic societies, Connors observes, "the need of the citizenry to have access to the information that allows it to judge how the democratic process is working remains constant," concluding, "As archivists, as members of the larger information profession, and as citizens of democratic societies, we have a definite stake in working to restore and expand open access to government information as a means of protecting our fragile democracies." ${ }^{27}$ Having been

\footnotetext{
${ }^{22}$ Kaye, “Why Do Ruling Classes Fear History?” 19.

${ }^{23}$ Kaye, "Why Do Ruling Classes Fear History?" 23.

${ }^{24}$ Thomas James Connors, “The Bush Administration and 'Information Lockdown," in Political Pressure, 195.

${ }^{25}$ Connors, "The Bush Administration," in Political Pressure, 199.

${ }^{26}$ Connors, "The Bush Administration," in Political Pressure, 202. For further background on the struggle between Congress and the executive branch over control of presidential records, see Bruce P. Montgomery, "Presidential Materials: Politics and the Presidential Records Act," American Archivist 66 (Spring/Summer 2003): 102-38.

${ }^{27}$ Connors, "The Bush Administration," in Political Pressure, 208.
} 
entrusted with responsibility for keeping records, archivists have not only an interest in but also an obligation to ensure open access for the wider public good. In examining access policies for State Department records, Anne Van Camp states, "One hallmark of a society's openness is the degree of public access to the archives and records of its government."28

Problems of government secrecy and the dangers of political influence on recordkeeping have ancient origins. "Written texts entrenched theocratic tyranny over vast reaches of monotheistic time and space," according to David Lowenthal. "Most archives originated as instruments of landowners' and lawgivers' control. ... Archives confirmed and certified rights to land, labor, rents, and produce. Entry to archives was confined to princely, priestly, and scribal elites."29

The willingness of archivists in recent years to speak out in defense of open government and access to records is a positive sign, amid the appalling abuses of power represented in the George W. Bush administration's efforts to shut down such access. SAA has taken public positions opposing government secrecy, and it entered several lawsuits seeking to ensure open access to public records. In 2005, SAA joined numerous other organizations as a member of OpenThe Government.org, a watchdog for unjustified secrecy and limited access to information about public officials and their actions. This organization's motto is "Americans for Less Secrecy, More Democracy." ${ }^{30}$ This principle is a vital part of the American archival profession's mission.

In numerous countries throughout the world, archivists and others entrusted with public records have resisted political pressure in order to maintain open access to records. They have thereby sought to preserve an accurate account of past events, to counteract the natural secretiveness of governments, and to protect the public interest. This has made the archives-particularly governmental archives-contested ground for political power. As Verne Harris argues, "the archive is politics-not that it is political, but that it is politics." Harris explains:

The structural pull in all our recordmaking is towards the replication of existing relations of power, with the attendant exclusions, "privilegings," and marginalisations. We cannot avoid complicity. But we can work against the pull; and for me it is a moral imperative to do so. ${ }^{31}$

\footnotetext{
${ }^{28}$ Anne Van Camp, “Trying to Write 'Comprehensive and Accurate' History of the Foreign Relations of the United States: An American Perspective," in Archives and the Public Good, 229.

${ }^{29}$ David Lowenthal, “Archives, Heritage, and History," in Archives, Documentation, and Institutions of Social Memory: Essays from the Sawyer Seminar, ed. Francis X. Blouin, Jr. and William G. Rosenberg (Ann Arbor: University of Michigan Press, 2006), 194.

${ }^{30}$ See website at http://www.openthegovernment.org.

${ }^{31}$ Harris, “Archives, Politics, and Justice," in Political Pressure, 173.
} 
Harris calls for archivists to enter the power struggles on the side of social justice. He argues that recordmakers (including archivists) cannot be impartial or insulate themselves from politics. "Impartiality is a chimera turning recordmakers into the pawns of those who have power," he argues. "Any attempt to be impartial constitutes a choice, whether conscious or not, to replicate if not to reinforce prevailing relations of power." If archivists do not enter the power contests on behalf of democracy, Harris concludes, "then they turn their backs on higher callings and condemn themselves to being merely bureaucrats and functionaries." 32 This call to action would place archivists clearly on the side of democracy, truth, and justice. It does not inherently require archivists to assume a partisan position, but it does require them to acknowledge that their profession is inherently and unavoidably engaged in political power struggles to define the nature of our societies.

Examples of international struggles to protect the archival record from partisan control and misuse can be seen in post-World War II Japan and other Asian countries, in Germany during the Cold War, in the Netherlands, and in numerous other countries. ${ }^{33}$ One noteworthy example of the essential nexus between democratic rule and access to public records comes from the Republic of Korea. As Kyong Rae Lee declares, "The modern development of presidential records in the Republic of Korea demonstrates a close relationship with political democracy. . . . The health of the Korean archival system is keenly sensitive to the level of Korean society's political maturity." 34 Archives can thus play a vital role in ensuring and fostering the open inquiry and access to information that are critical to democratic governments.

\section{Soctal Justice}

Archives and the quest for social justice connect most dramatically in South Africa, which has undergone a long and difficult transition from the oppressive apartheid regime to democracy. "Under apartheid, the terrain of social memory, as with all social space, was a site of struggle," according to South African archivist Verne Harris. "In the crudest sense it was a struggle of remembering

\footnotetext{
${ }^{32}$ Harris, “Archives, Politics, and Justice," in Political Pressure, 181-82.

${ }^{33}$ See for example these articles in Procter, et al., Political Pressure: Masahito Ando, "The Asian-Pacific War and the Fate of Archives," 3-23; Friedrich Kahlenberg, "Governmental Rule and Archivists: The Historical Experience of the Twentieth Century in Central Europe,” 59-71; Astrid M. Eckert, “ ‘. . .And Grant German and Foreign Scholars Access at All Times': Archival Access in West Germany During the Cold War," 75-91; Agnes Jonker, "Srebenica: A Balkan Tragedy and the Making of a Dutch Affair," 277-88; and others.

${ }^{34}$ Kyong Rae Lee, "Political Democracy and Archival Development in the Management of Presidential Records in the Republic of Korea," American Archivist 69 (Spring/Summer 2006): 136-37.
} 
against forgetting, of oppositional memory fighting a life-and-death struggle against a systematic forgetting engineered by the state." To maintain its power, the apartheid government "generated huge information resources, which it secreted jealously from public view. It routinely destroyed public records in order to keep certain processes secret." ${ }^{35}$ Control over records formed part of a broader exercise of state power. "In imposing apartheid ideology, the state sought to destroy all oppositional memory through censorship, confiscation, banning, incarceration, assassination, and a range of other oppressive tools," Harris reports. ${ }^{36} \mathrm{He}$ suggests that the lessons to learn from this include "the necessity for transparency and accountability in government"; "the public right of access to information, particularly that held by the state"; the need for clear archival selection procedures, "choosing what to remember and what to forget"; and "the need for a democratic state to take appropriate measures to prevent the sanitizing of official memory resources." ${ }^{37}$ Harris's account highlights the essential nature of proper recordkeeping to protect citizens' rights and to secure social justice.

In the 1980s, the South African History Archives (SAHA) deliberately sought to counter "the dominant narratives of the Apartheid regime." In his presentation at the July 2003 Liverpool conference on "Political Pressure and the Archival Record," Verne Harris argued that SAHA's "most important accounting is to the call of justice." The question Harris addressed was, "Why 'archives for justice' rather than 'archives for truth,' 'archives for memory,' or 'archives for accountability'?” His experience in South Africa convinced him that "the call of justice is the most important of all." Since elites "use 'the archive' as an instrument of power," it is a moral imperative to counter such control and the abuses it can create. ${ }^{38}$ Harris has been a leading figure in efforts to overturn South Africa's apartheid-era culture of political secrecy and control of records, and to replace it with a more transparent and open archival process. The Truth and Reconciliation Commission used records and archives to uncover past abuses under the old regime, although access to such records remains hotly contested. For example, recent changes in archival policy have brought "the National Archives more tightly under the control of the bureaucracy," and access policy to the records of the Truth and Reconciliation Commission has still not been finalized. Valuable records in the Transkei archives have been exposed

${ }^{35}$ Verne Harris, “'They Should Have Destroyed More': The Destruction of Public Records by the South African State in the Final Years of Apartheid, 1990-1994," in Archives and the Public Good, 205.

${ }^{36}$ Harris, "Redefining Archives," 173-74.

${ }^{37}$ Harris, "Archives, Politics, and Justice," in Archives and the Public Good, 224-25.

${ }^{38}$ Harris, "Archives, Politics, and Justice," in Political Pressure, 177-78. For more on SAHA, see Harris, "Using the Promotion of Access to Information Act (PAIA): The Case of the South African History Archive," in Archives and Justice, 337-49. 
to improper storage, showing "a reckless disregard for the preservation of a priceless and irreplaceable resource." 39 Despite these obstacles, the efforts of South African archivists provide a documentary basis for efforts to secure a greater degree of social justice in their troubled nation.

South Africa is one of many countries that established truth commissions in recent years to overcome secrecy and expose past social injustices. Nearly two dozen truth commissions have been established, most in South and Central America and Africa, as temporary bodies set up to investigate abuses of former repressive regimes when countries transition to more democratic rule. As Trudy Peterson concludes after studying twenty such truth commissions:

Oppressive regimes try to impose selective amnesia on society. The purpose of a truth commission is to break through that wall of silence and restore knowledge of the hitherto hidden hands in history. Destroying the records ensures that only those things that made their way into the report will be remembered officially, and thereby opens the way for persons opposed to the commission to win yet again. Saving the records ensures that amnesia does not prevail. ${ }^{40}$

Archival preservation of truth commission records protects the rights of individual victims to know the truth. "The right to know is also a collective right, drawing upon history to prevent violations from recurring in the future," according to distinguished legal scholar Louis Joinet in a report to the United Nations Commission on Human Rights. "Its corollary is a 'duty to remember,' which the State must assume, in order to guard against the perversions of history that go under the names of revisionism or negationism; the knowledge of the oppression it has lived through is part of a people's national heritage and as such must be preserved." 41 Placed in national archives or other safe repositories, such records provide a bulwark for social justice and a means to redress past abuses.

One of the most highly publicized international efforts to use records and archives to redress past injustices has been the campaign to restore Holocaustera assets to the families of Nazi victims. "The Nazi era witnessed the direct and indirect theft of well over $\$ 150$ billion of assets of victims of Nazi persecution," according to Greg Bradsher. ${ }^{42}$ In seeking to uncover the extent of such misappropriation, researchers relied extensively on records held by the United States National Archives and Records Administration.John W. Carlin, then Archivist of the United States, declared, "Everyone should understand the role of the records

${ }^{39}$ Harris, "Archives, Politics, and Justice," in Political Pressure, 180-81.

${ }^{40}$ Trudy Huskamp Peterson, Final Acts: A Guide to Preserving the Records of Truth Commissions (Washington, D.C.: Woodrow Wilson Center Press, 2005), 1-2.

${ }^{41}$ Peterson, Final Acts, 8.

${ }^{42}$ Greg Bradsher, "Turning History into Justice: The National Archives and Records Administration and Holocaust-Era Assets, 1996-2001," in Archives and the Public Good, 178. 
in establishing and legitimizing identities and liberties." ${ }^{43}$ As a 1998 U.S. News and World Report article declared, archival institutions "have become drivers of world events. Their contents have forced apologies from governments, opened longdormant bank accounts, unlocked the secrets of art museums, and compelled corporations to defend their reputations." 44 The Vilnius Forum on Looted Cultural Property adopted a declaration that, in part, recognized the need "to ensure that archives remain open and accessible and operate in as transparent a manner as possible." As Bradsher concludes, archives have served "as important resources in the search for truth and justice, and as Stuart Eizenstat frequently says, turning history into justice." ${ }^{55}$ The Holocaust assets project thus demonstrates the value of archives in the quest for justice.

Another example of success in using archival records to redress past injustices is the exposure of the Tuskegee syphilis study. Lasting from 1932 to 1972, this study by the United States Public Health Service allowed 399 AfricanAmerican men to suffer and die from syphilis without receiving treatment. This unethical study has been called the "longest non-therapeutic experiment on human beings in medical history." ${ }^{6}$ The original records of this study provide the evidence necessary to hold the U.S. government accountable for its actions. Discussing this case, Tywanna Whorley insists:

For records that reveal illegal and improper governmental actions, archivists must not hesitate in exposing the existence of such records. As Kent Haworth states, "The ... purpose of the archivist is to hold in trust for society the evidence of the truth, the evidence of justice and injustice in the society our archives document." 47

However, as Whorley charges, the National Archives and Records Administration refused to make these records openly accessible, despite public demand for government accountability, due to an "archival policy on restricting archival records that contain personal information without reconciling the right to know versus the right to privacy." ${ }^{18}$ Despite continuing controversy over releasing these records, their existence offers at least some assurance of the power of records to secure a measure of social justice for those who have suffered from government mistreatment.

\footnotetext{
${ }^{43}$ Bradsher, "Turning History into Justice," in Archives and the Public Good, 177.

${ }^{44}$ Bradsher, "Turning History into Justice," in Archives and the Public Good, 194.

${ }^{45}$ Bradsher, "Turning History into Justice," in Archives and the Public Good, 199-200.

${ }^{46}$ Tywanna Whorley, “The Tuskegee Syphilis Study: Access and Control Over Controversial Records," in Political Pressure, 110.

${ }^{47}$ Whorley, "Tuskegee Syphilis Study," in Political Pressure, 110-11. Haworth is quoted from his article, "The Principles Speak for Themselves: Articulating a Language of Purpose for Archives," in The Archival Imagination: Essays in Honour of Hugh Taylor, ed. Barbara L. Craig (Ottawa: Association of Canadian Archivists, 1992).

${ }^{48}$ Whorley, "Tuskegee Syphilis Study," in Political Pressure, 116-17.
} 
These are but four of numerous recent instances in which records and archives contribute to social justice by holding accountable those responsible for abuses of trust and power. By preserving records that can provide evidence of injustice, archivists can contribute positively to attempts to overcome past uses of archives and records by elites to secure power. Such benefits can also be seen in Sierra Leone, where records management improvements have been targeted to support the "Poverty Reduction Strategy" and national recovery from a tenyear civil war. In 2003, President Kabbah declared, "The poor storage and retrieval of information slows down work of the public service and impacts negatively on policy formulation, planning and financial control. The improvement of record keeping is absolutely essential for moving the reform process forward." 49 Archival protection of records thus serves the vital need to ensure social justice and protect citizens' rights. As John McDonald states, "Without records, there can be no demonstration of accountability. Without evidence of accountability, society cannot trust in its public institutions." 50

Diversity

Archivists make significant contributions to a more representative and just society by creating racial, ethnic, and community-based repositories. As Elisabeth Kaplan has shown, such repositories play important roles both in promoting a more diverse society and in fostering community identity among groups often marginalized by more powerful elites. ${ }^{51}$ An oft-voiced professional credo that is not always followed states that the archival "record must reflect full diversity and complexity, not an edited compendium that celebrates a specific world view or a single group." 52 In the 1960s, a number of archivists responded to the challenge raised by social activists and began developing plans for documenting underrepresented social groups. ${ }^{53}$ Among the most encouraging developments of the past forty years, from

\footnotetext{
${ }^{49}$ Sarah Demb, "Vital Records and Cultural Heritage: The Role of the National Archives in the Governance of Sierra Leone," unpublished paper presented to the Association of Canadian Archivists 2006 annual meeting.

${ }^{50} \mathrm{John}$ McDonald, "Accountability in Government in an Electronic Age" (1998), available at International Records Management Trust website: http://web.archive.org/web/20010726105930/ www.irmt.org/education/malpaper2.html, accessed 11 May 2007.

${ }^{51}$ Elisabeth Kaplan, "We Are What We Collect, We Collect What We Are: Archives and the Construction of Identity," American Archivist 63 (Spring/Summer 2000): 126-51.

${ }^{52}$ Diane Vogt-O'Connor, "Is the Record of the Twentieth Century at Risk?" quoted in Lowenthal, "Archives, Heritage, and History," in Archives, Documentation, and Institutions of Social Memory, 200.

${ }^{53}$ Howard Zinn, "The Archivist and Radical Reform," unpublished manuscript quoted in F. Gerald Ham, "The Archival Edge," American Archivist 38 (January 1975): 5; Sam Bass Warner, Jr., "The Shame of the Cities: Public Records of the Metropolis," Midwestern Archivist 2, no. 2 (1977): 27-34; Patrick M. Quinn, "Archivists and Historians: The Times They Are A-Changin'," Midwestern Archivist 2, no. 2 (1977): 513.
} 
the perspective of social diversity, are the number of archival repositories dedicated to documentation of African Americans and racial/ethnic groups, gay and lesbian communities, laborers, and other marginalized communities. Although public and academic repositories actively collect their records, many of these groups have seized the initiative to document their own lives and tell their own stories.

Jeannette Bastian shows that even among a people whose history was never recorded-the natives of the Virgin Islands-a creative approach to archival documentation can provide a communal history and identity. "Throughout the 250-year colonization of the islands, the Danish colonial bureaucracy kept meticulous records and when the Danes left the islands [in 1917], they took most of these records with them and deposited them in the Danish National Archives in Copenhagen," Bastian explains. The National Archives of the United States claimed similar records when the islands fell under American control: "Except for property records and some court records, the only records found in the Virgin Islands today are contemporary ones dating from the mid-twentieth century." ${ }^{44}$ The problem for colonial peoples is not that their history under foreign control has been forgotten, but that it "was never recorded, therefore not remembered [officially]," Bastian observes. "Archives can provide the key to that quest if the searcher recognizes that records have both a text and a subtext, that records are both evidence and action, and that behind the record lies the trace." ${ }^{55}$ As one Virgin Islander argues, “. . . it's our story and we should have access to it, when we need to have access to it to even write our story or even just to understand, to have a complete picture ... otherwise anyone could tell you anything they want." ${ }^{26}$ These various efforts to expand archival documentation beyond the elitist focus on the "great white males" of previous generations promise a more representative depiction of society and of human history.

The "new social history" of the 1960s led to expansion of source materials for underrepresented groups in American society. "Literally an embarrassment of riches, documentation of the lives of women, workers, farmers, enslaved persons, and Native Americans flushed out a disquieting connection between history and national identity," according to historian Joyce Appleby ${ }^{57}$ When the disenfranchised find themselves excluded from existing repositories, they sometimes create their own archives. ${ }^{58}$ Women, ethnic and racial groups, religious

\footnotetext{
${ }^{54}$ Jeannette Allis Bastian, "Whispers in the Archives: Finding the Voices of the Colonized in the Records of the Colonizer," in Political Pressure, 34, 27-28. See also Bastian, Owning Memory: How a Caribbean Community Lost Its Archives and Found Its History (Westport, Conn.: Libraries Unlimited, 2003).

${ }^{55}$ Bastian, "Whispers in the Archives," in Political Pressure, 26-29.

${ }^{56}$ Bastian, "Whispers in the Archives," in Political Pressure, 32.

${ }^{57}$ Joyce Appleby, A Restless Past: History and the American Public (Lanham, Md.: Rowman and Littlefield, 2005), 139.

${ }^{58}$ Kaplan, "We Are What We Collect," 126-51.
} 
communities, laborers, and other marginalized communities have established archival repositories to document and celebrate their histories and cultures. Other repositories, which have a broader collecting and documentation mandate, incorporate diversity goals into their program priorities. These voices confer power. Archives provide a forum to recognize and legitimize the role of disenfranchised groups in society.

For African Americans, for instance, the development of an archival presence represents both an assertion of racial pride and an effort to secure the power that comes from being able to tell the group's collective story of tragedy, suffering, achievement, and success. As early as 1914, several universities and libraries established research collections focusing on the African-American experience in the United States. These include the Schomburg Center for Research in Black Culture ${ }^{59}$ at the New York Public Library, the MoorlandSpingarn Research Center ${ }^{60}$ at Howard University, and the Amistad Research Center ${ }^{61}$ at Tulane University. "These are notable beginnings by Negroes in the preservation of the evidence of their accomplishments," Harold T. Pinkett wrote in 1944. However, "Much more can and needs to be done. To begin with, the nature and value of existing collections should be more widely publicized with a view toward stimulating more interest in documentary materials." 62

In addition to repositories established to document the broad range of African-American and minority history, several focus specifically on the modern civil rights movement itself. These deliberate efforts to preserve the perspective of the movement or to memorialize civil rights leaders take an openly partisan or celebratory approach to the subject. Some of them are housed within civil rights museums or in research institutions with a special interest in civil rights. Examples include the King Center in Atlanta, ${ }^{63}$ the Birmingham Civil Rights Institute ${ }^{64}$ and the Civil Rights in Mississippi Digital Archive at the University of Southern Mississippi. ${ }^{65}$ These institutions actively seek to shape the public

\footnotetext{
${ }^{59}$ Schomburg Center for Research in Black Culture, "History and General Information," available at http://www.nypl.org/research/sc/about/history.html," accessed 10 May 2007.

${ }^{60}$ Thomas C. Battle, "Moorland-Spingarn Research Center," Library Quarterly, 58, no. 2 (1988): 143-63 and http://www.founders.howard.edu/moorland-spingarn/HIST.HTM, accessed 10 May 2007.

61 "Amistad Research Center," available at http://www.amistadresearchcenter.org, accessed 10 May 2007.

${ }^{62}$ Harold T. Pinkett, "Preserving the Past for the Present," The Crisis, February 1944, 57, reprinted in “Archivists and Archives of Color Newsletter," American Archivist 15, (Spring/Summer 2001): 3.

${ }^{63}$ King Center, "The King Center's Mission," available at http://www.thekingcenter.com/tkc/mission.asp, accessed 10 May 2007.

${ }^{64}$ Birmingham Civil Rights Institute, “Archives Division,” available at http://www.bcri.org/index.html, accessed 10 May 2007.

${ }^{65}$ University of Southern Mississippi, "About the Civil Rights in Mississippi Digital Archives," available at http://www.lib.usm.edu/ spcol/crda/about.htm, accessed 10 May 2007.
} 
discourse on civil rights and sometimes even attempt to advocate a particular interpretive vision of the movement. Such efforts may blur the line between scholarship and political power.

Closely related to the concept of power is that of identity. The King Center in Atlanta deliberately seeks to shape the public memory of one of the leaders of the civil rights movement. According to its mission statement, "Established in 1968 by Mrs. Coretta Scott King, the King Center is the living memorial and institutional guardian of Dr. Martin Luther King, Jr.'s legacy." ${ }^{6}$ The King Library and Archives shares the center's purposes: "The King Library and Archives' mission is to promote the appropriate application of archival principles in the preservation, processing, and description of materials relevant to the life and work of Dr. Martin Luther King, Jr. and the modern civil rights movement." 67 In addition to the papers of Dr. King, the Library and Archives maintains the records of many civil rights organizations and the personal papers of other civil rights activists. This confers legitimacy on them as part of the movement's legacy.

Many civil rights archives focus on the formal records created by organizations engaged in civil rights activities-such as the National Association for the Advancement of Colored People, the Southern Christian Leadership Conference, and the Student Nonviolent Coordinating Committee-and on the personal papers of nationally recognized figures such as King, Rev. Ralph Abernathy, and Rev. Fred Shuttlesworth. Historical studies of the movement depict these organizations and leaders most often, both because of their recognized prominence in civil rights and because records of their activities are readily available.

In contrast, Howard Zinn challenged archivists a generation ago to compile documentation of "the lives, desires, and needs of ordinary people."68 Since then, significant progress has been made, but much more remains to be done. In documenting diversity in our society, notable achievements in preserving records of prominent organizations and papers of individual leaders have been made. But archival repositories still need to turn their attention to collecting and preserving the records of ordinary people. These forgotten voices continue to represent an underdocumented texture in our social fabric.

\footnotetext{
${ }^{66}$ King Center, "The King Center's Mission," available at: http://www.thekingcenter.com/tkc/ mission.asp, accessed 10 May 2007.

${ }^{67}$ King Center, "King and the Modern Civil Rights Movement Scholar and Historian Research Program," available at http://www.thekingcenter.com/prog/research.html, accessed 10 May 2007.

${ }^{68}$ Howard Zinn, "Secrecy, Archives, and the Public Interest," Midwestern Archivist 2, no. 2 (1977): 25.
} 
If archivists are to avoid perpetuating situations in which political rulers manipulate records to control history and prevent access to accurate information, they have their work cut out for them. Archivists need to recognize that their social role has significant implications and a high degree of power. As Verne Harris argues, "the archive is politics." Archivists cannot escape by hiding behind a veil of innocence, neutrality, and impartiality. "I would insist that even as we impress upon our students the imperative and value of objectivity and its limits, we must reject the spurious equation of objectivity with neutrality," historical sociologist Harvey Kaye admonishes his fellow teachers, "and encourage students to apply their newly acquired scholarly skills, knowledge, and insights both to analyzing and to speaking out on public issues." ${ }^{69}$ Archivists should heed this call to activism. It is essential to seize the power of archives and to use it to hold institutional and governmental leaders accountable. All aspects of society should be documented, not simply those where power has traditionally resided. As Terry Cook argues, "The justification for archives has shifted from being grounded in concepts of the nation state and its scholarly elites (primarily historians) to broader socio-cultural justifications grounded in public policies of accountability, freedom of information, and wider public/citizen use."70

In considering what archivists can do in their professional roles to strengthen the cause of social justice, we need to look first at archivists' external relations with recordmakers, donors, researchers, and employers. Public advocacy is essential for the archival profession's survival. It is also the most direct means by which it can contribute to the public interest. First, archivists must sometimes be willing to take a public stand, or a nonpublic position in certain situations when publicity could be counterproductive. Second, archivists need to re-examine their own professional assumptions, methods, and practices in light of the desired outcomes of justice and diversity. There is no easy solution for the longstanding problems of social injustice, discrimination, and unchecked political power.

Using examples of past and present successes in asserting the power of archives as a guide, I would like to conclude by offering a few suggestions as to how archivists can respond to these monumental challenges. For now, these recommendations are necessarily broad and aspirational. Once archivists accept such strategic goals, their next steps will be to fill in the details and action plans.

Before opening this discussion, however, we must distinguish between the terms neutrality and objectivity. We often speak of neutrality and objectivity as

\footnotetext{
${ }^{69}$ Kaye, "Why Do Ruling Classes Fear History?” 153.

${ }^{70}$ Terry Cook, "The Archive Is a Foreign Country: Historians, Archivists, and the Changing Archival Landscape," Canadian Historical Review (forthcoming as of November 2007).
} 
synonymous, or as two sides of the same relationship between individuals and the expression of their values and perspectives toward contested issues. In an extensive critique of the development of the American historical profession, Peter Novick contends that the "ideal of 'objectivity' . . . has been the key term in defining progress in historical scholarship: moving ever closer to the objective truth about the past." Novick states, "The objective historian's role is that of a neutral, or disinterested, judge; it must never degenerate into that of advocate or, even worse, propagandist." In adhering to this ideal, historians must display "judicial qualities of balance and evenhandedness," avoid "partisanship or bias," and "purge themselves of external loyalties" [i.e., outside the profession]. ${ }^{71}$ Novick contends that the "myth of objectivity" leads historians to avoid controversy within the discipline and blocks them from taking positions on social and political issues. “ 'Objectivity' has been one of the central sacred terms of professional historians, like 'health' for physicians, or 'valor' for the profession of arms," he asserts. Similarly, lawyers invoke "justice" and journalists pledge fealty to "a free press in a free society." embraced the model of scientific method, which Novick characterizes as "rigidly factual and empirical, shunning hypothesis," and as "scrupulously neutral" on matters of meaning and purpose.$^{73}$ Because this concept of objectivity both sets an impossible objective and also precludes historians from advocating social or political causes, Novick rejects the ideal as "not just essentially contested, but essentially confused."74

In a highly critical review of Novick's book, Thomas Haskell argues that the central fallacy that Novick and others perpetuate is to conflate objectivity with neutrality. Haskell defends the validity of the concept of objectivity, while attempting to rid it of "unwanted connotations" such as neutrality, selflessness, and passivity. "Objectivity is not something entirely distinct from detachment, fairness, and honesty, but is the product of extending and elaborating these priceless and fundamentally ascetic virtues," Haskell contends. ${ }^{75}$ Historians (and others) can be objective without forsaking engagement in discussions of values, politics, or social policy. "The demand is for detachment and fairness, not disengagement from life," he argues. The historian's "primary commitment" to

${ }^{71}$ Peter Novick, That Noble Dream: The "Objectivity Question" and the American Historical Profession (New York: Cambridge University Press, 1988), 1-2.

${ }^{72}$ Novick, That Noble Dream, 11.

${ }^{73}$ Novick, That Noble Dream, 37.

${ }^{74}$ Novick, That Noble Dream, 6.

75 Thomas L. Haskell, Objectivity Is Not Neutrality: Explanatory Schemes in History (Baltimore: Johns Hopkins University Press, 1998), 149-50. See also Haskell, "Objectivity: Perspective as Problem and Solution," History and Theory 43 (October 2004): 341-59. 
truth does not prohibit political advocacy, Haskell states, but it does "set intellectually responsible limits to it," so that one cannot claim "the privilege of lying or obscuring the truth for good causes."76

Professional standards, including objectivity, need not prevent us from addressing moral, ethical, or political issues. A common fallacy is to equate objectivity with neutrality. ${ }^{77}$ One can maintain professional standards even while advocating a cause or defending a moral or ideological perspective. Haskell states that "there is widespread recognition within the [historical] profession that political commitment need not detract from the writing of history-not even from its objectivity - as long as honesty, detachment, and intelligence are at work."78 Sustaining intellectual and professional principles-such as "respect for logical coherence, fidelity to evidence, detachment, candor, honesty, and the like"-must accompany any advocacy for moral or political values. As Haskell warns, "When the members of the scholarly community become unwilling to put intellectual values ahead of political ones, they erase the only possible boundary between politically committed scholarship and propaganda and thereby rob the community of its principal justification for existence."79 These criteria provide a context within which professional debate can occur.

Using the Power of Archives

By recognizing the distinction between objectivity and neutrality, it is possible for a historian-or archivist or librarian-to engage in moral or political advocacy without sacrificing his or her professional standards. However, in promoting accountability and social justice, for example, archivists should consider developing the framework for what James O'Toole calls "a moral theology of archives." "When archivists appraise and acquire records, when they represent them in various descriptive media, when they make them available for use, they are engaging in activities that have moral significance beyond the immediate concerns of managing forms of information," O'Toole argues. These archival responsibilities suggest "how a concern for historical accountability is a part of the archival mission, a way of elaborating a practical moral theology of archives." ${ }^{80}$ Such a moral vision goes beyond the limited perspective of

\footnotetext{
${ }^{76}$ Haskell, Objectivity Is Not Neutrality, 155.

${ }^{77}$ Mea culpa. In "Embracing the Power of Archives" I fell into the same trap that ensnares many who argue that abandoning the "illusion of neutrality" also requires abandoning the ideal of objectivity.

${ }^{78}$ Haskell, Objectivity Is Not Neutrality, 167.

${ }^{79}$ Haskell, Objectivity Is Not Neutrality, 168.

${ }^{80}$ James O'Toole, "Archives and Historical Accountability: Toward a Moral Theology of Archives," Archivaria 58 (Fall 2004): 14.
} 
professional ethics, but it reaffirms rather than overturns professional principles. Commitment to honesty, fairness, and truth provides the necessary grounding in "objectivity." As the postmodernists remind us, however, these virtues are not absolute, but are contingent and contested. Even with such cautions, archivists can proceed to engage the public discourse on concerns arising from their professional responsibilities.

Verne Harris provides valuable suggestions for wrestling with the challenge of articulating an activist role within the constraints of professional obligations. "There is no knowing of right without giving account to personal morality," he declares. None of us can be truly impartial. "The most we can do is ensure that in taking difficult decisions we have done so in an appropriate way," Harris states. This includes understanding "the web of rights" for all parties, "weighing competing claims" within specific circumstances, testing the archivist's "views and feelings with respected colleagues and friends," and "finally, paying heed to one's conscience." Harris cautions

If we follow conscience without taking the first three steps, we abandon accountability and risk assuming godlike powers. If we ignore conscience and rely only on the exercise of reason, we deny our humanity and seek to avoid bearing the burden of choice. It is only when we embrace all four elements that we can feel confident about having fulfilled the responsibilities invested in us as professionals. ${ }^{81}$

Harris concedes the dangers of abandoning the archivist's image as a neutral party in ideological or political contests. "Give up on the notion of the archivist as impartial custodian, as honest broker, and one opens the door to activist archivists pursuing any and every political agenda," he warns. ${ }^{82}$ However, the "greater danger" is that in claiming an impartiality impossible to achieve, archivists will become "pawns in bigger power plays." Challenging those in power carries risks. "To access resources, to secure the status we need to do what we have to do effectively, we are forced to adopt neat theorizing to a greater or lesser degree," Harris concedes. "My call is simply to remember this. ... Knowledge is always contingent, always standing above an abyss." ${ }^{83}$ The challenge facing archivists-and anyone else contending with the competing demands of morality, politics, professional standards, and funding imperatives-is to articulate a vision that balances these considerations. In doing so, archivists need to heed the call to honesty, fairness, accountability, justice, and transparency in their professional practice.

\footnotetext{
${ }^{81}$ Harris, "Knowing Right from Wrong: The Archivist and the Protection of People's Rights," in Archives and Justice, 211.

${ }^{82}$ Harris, "The Archive Is Politics," in Archives and Justice, 247.

${ }^{83}$ Harris, "The Archive Is Politics," in Archives and Justice, 248-49.
} 
Archivists can begin by recognizing the essential nature of their collective responsibility to ensure the preservation of evidence for accountability, individual rights, and social justice. As Harvey Kaye declares, "following the horrors of the past several generations, the persons who should be accorded the greatest recognition are those who, taking up the task of bearing witness to the exterminations, the massacres, the tortures, direct our thoughts to the past and to the imperatives of remembrance, realizing that the final victories of the murderers and the torturers would be the suppression, deliberate or otherwise, of the knowledge of their criminal acts." Kaye cites the Memory Prize, first awarded by the France-Libertes Foundation in 1989, as a promising recognition of the importance of this human need: "Intended to recognize those who labor to secure our collective memory and to prevent the falsification of the historical record, the idea for the prize arose out of the growing awareness that 'the expression, transmission, and preservation of Human Memory is the most effective means of struggling against the recurrence of barbarism." "84 Given the nature and significance of this award, archivists should aspire to see members of their profession so recognized. Short of this, they can take important steps to support a more just and equitable society by performing their professional responsibilities.

First, when confronted by external pressures (from administrators, donors, constituents, or others) to alter recordkeeping systems or archival practices, archivists and records managers must stand firm. Archivists must protect the integrity of their records and of the recordkeeping systems that hold organizations and individuals accountable. This adherence to professional principles applies equally in public and private institutions, although protections for those who resist such pressures will vary from one setting to another. As in the case of South African archivists under apartheid (and after the end of apartheid), archivists must defend the public's right of access to the most accurate records possible, despite political pressure ${ }^{85}$ The Heiner affair in Australia also illustrates the importance of refusing to succumb to political pressure to change archival recordkeeping procedures. As these examples indicate, resisting political pressure can entail personal risk. Although such situations are rare, members of a profession should be willing to consider such risks.

Second, when such pressures cannot be resisted, archivists and records managers must be willing to become whistleblowers, speaking out against abuses of power or efforts to manipulate records or limit access to information. This situation may not commonly occur, but it can happen when archivists least

\footnotetext{
${ }^{84}$ Kaye, "Why Do Ruling Classes Fear History?" 60-61.

${ }^{85}$ Harris, "Redefining Archives in South Africa," 173-74.
} 
expect it and they must be prepared to respond forcefully when it does. The courage shown by Shelley Davis in her heroic but ultimately unsuccessful struggle to prevent "massive document destruction" and to overcome barriers to public access to Internal Revenue Service (IRS) records should be an inspiration to all of us. Hired as the first historian of the IRS, Davis attempted to accumulate historical records as a basis for her research. She found few such records, because the IRS routinely destroyed most of them, resulting in "essentially the wholesale loss of the history of one of our most important government agencies." As Davis discovered, "The IRS shredded, burned, trashed, and destroyed nearly their entire record path." This behavior would not change, Davis concluded, until "the National Archives becomes more proactive in demanding that the IRS open its records." ${ }^{86}$ Davis's courage in confronting this problem demonstrates the need for archivists, on rare occasions, to act as whistleblowers when confronted by improper recordkeeping. It is also a warning, of course, of the extent to which powerful government agencies can go to protect their secrets.

Third, both individually and collectively, archivists must speak out in defense of archival values, including open access to public records, standards of accountability and authenticity, and protection of the rights of all citizens. Tim Ericson chides archivists for a "lackadaisical attitude" toward government secrecy. "Collectively we have acquiesced uncritically to those who call for patriotism, national security, loyalty, [etc.]," he charges. "Archivists should be acquiescent no more! We should instead begin to be aggressive as professionals and as citizens to fight this unprecedented tilt toward secrecy." 87 There are hopeful signs that archivists are becoming more assertive on this issue. SAA has taken a collective stance in several recent public controversies: opposing the executive order claiming presidential control over public records; criticizing Mayor Rudy Giuliani's refusal to turn over his mayoral records to a public repository; joining a lawsuit (unsuccessful) to force Vice President Dick Cheney to disclose the names of participants in a secret energy policy meeting; and supporting the right of "Unabomber" Ted Kaczynski to place his papers at a public university repository. These are all steps in the right direction, but archivists can and should do more, both by professional associations and as individuals.

\section{Archival Functions}

In addition to these external perspectives-how archivists respond to the challenges outside their repositories-archivists also need to look at their own

\footnotetext{
${ }^{86}$ Shelley Davis, "The Failure of Federal Records Management: The IRS versus a Democratic Society," in Archives and the Public Good, 115, 117, 133.

${ }^{87}$ Ericson, "Building Our Own ‘Iron Curtain'," 51.
} 
professional practices. Archival principles and functions developed largely in the context of nineteenth-century bureaucratic states. The principle of provenance, for example, reflects assumptions about organizational structures and hierarchies ${ }^{88}$ that privilege those in power and those with a recognized collectivity. The experience of Jeannette Bastian in the Virgin Islands confirms the arguments of Hugh Taylor and Terry Cook that a broader concept of provenance is needed in some contexts. Taylor argued in 1970 that archivists should focus more on why and how people create documentation, rather than on its subject content. This would extend our understanding of the provenance of documentation deeply into the societal origins of human communication. ${ }^{89}$ As Bastian discovered in the Virgin Islands, "records become 'witnesses' to a silent society, a community that is the subject of the records rather than their maker but one that is no less involved in their creation." To ensure that "the voiceless population is not the silent witness but a full partner in the record-creating process," Bastian argues that "all layers of society are participants in the recordmaking process, and the entire community becomes the larger provenance of the records." ${ }^{90}$ Likewise, Adele Perry contends that "the absences in the colonial archive are not neutral, voluntary, or strictly literal"; they are "silences borne of and perpetuated by violence and radical inequality." 91

Concern for the "voiceless populations" in society should also lead archivists to adjust their procedures for all basic archival functions. In selection and appraisal, they need to be conscious of the potential bias in their traditional methods. Archival choices have long been shaped by the constraints of power relations and sources of funding. In examining the founding of the Mississippi State Archives under Dunbar Rowland, for example, Patricia Galloway concludes that there is "nearly always an inherent tension between what historians and archivists would like to collect and preserve and what economic and political constraints allow them to collect and preserve." ${ }^{2}$ To counter these biases, archivists should seek opportunities to preserve records of those often overlooked by their collecting strategies and recognize the broader concept of

\footnotetext{
${ }^{88}$ When I first typed this word it came out "hierarchives"-perhaps suggesting the close connection between traditional archival theory and practice and the hierarchical systems in which they have developed.

${ }^{89}$ Paraphrased from Tom Nesmith's commentary on Hugh Taylor, "Transformation in the Archives: Technological Adjustment or Paradigm Shift?" (1970), in Canadian Archival Studies and the Rediscovery of Provenance, ed. Tom Nesmith (Metuchen, N.J.: Scarecrow Press, 1993), 17.

${ }^{90}$ Bastian, "Whispers in the Archives," in Political Pressure, 41.

${ }^{91}$ Adele Perry, "The Colonial Archive on Trial: Possession, Dispossession, and History in Delgamuukw v. British Columbia," in Archive Stories: Facts, Fictions, and the Writing of History, ed. Antoinette Burton (Durham, N.C.: Duke University Press, 2005), 345.

92 Patricia Galloway, "Archives, Power, and History: Dunbar Rowland and the Beginning of the State Archives of Mississippi (1902-1936)," American Archivist 69 (Spring/Summer 2006): 80.
} 
provenance for an entire community (including those groups often marginalized or silenced by archival collecting policies and appraisal guidelines). For example, even within institutional archives, archivists could also recognize the historical value of records documenting workers, community relations, and other aspects of corporate or organizational activities beyond the legal, fiscal, and administrative requirements.

In making such decisions regarding archival selection and appraisal, archivists run the risk of intruding their own concepts of history and societyinto the archival record. However, this is an inevitable consequence of archival agency. As Eric Ketelaar explains, in making any appraisal or selection decision, "we alter [the records'] context and meaning, we infuse new meaning into the record, to what is left of the series and the fonds, we add new narratives to the

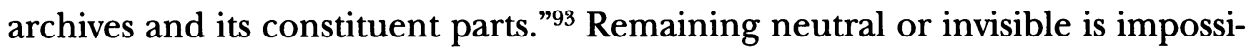
ble for archivists engaged in selection, appraisal, arrangement, description, and reference services. "Archivists inevitably will inject their personal values into all such activities," Terry Cook asserts, "and thus will need to examine very consciously their choices in the archive-creating and memory-formation processes, and they will need to leave very clear records explaining their choices to posterity." ${ }^{24}$ Archival appraisal typically reflects power relations established by state agencies, business corporations, religious establishments, academic institutions, and other power brokers. "In the records we preserve, too often the voices of the governed, especially the underclasses, are either filtered through the voices of bureaucrats or are absent," Verne Harris argues. ${ }^{95}$ The question is not whether archivists impose their personal interpretations, but whether they act consciously in doing so and whether they transparently document such decisions.

This impact on the meaning of archival records is nothing new. It is the power of interpretation, traditionally viewed as the preserve of historians and other researchers. As Michael Kammen argues in his study of the role of tradition in American history, we like to think of the past as immutable, based on truth and facts; however, "societies reconstruct their pasts rather than faithfully record them, and that they do so with the needs of contemporary culture clearly in mind-manipulating the past in order to mold the present." ${ }^{96}$ As archivists

\footnotetext{
${ }^{93}$ Eric Ketelaar, “Tacit Narratives: The Meaning of Archives,” Archival Science 1 (2001): 136.

${ }_{94}$ Terry Cook, "Remembering the Future: Appraisal of Records and the Role of Archives in Constructing Social Memory," in Archives, Documentation, and Institutions of Social Memory, 173. See also Verne Harris, "Postmodernism and Archival Appraisal: Seven Theses," in Archives and Justice, 101-6.

${ }^{95}$ Harris, "Exploratory Thoughts on Current State Archives Service Appraisal Policy and the Conceptual Foundations of Macro-Appraisal," in Archives and Justice, 93.
}

${ }^{96}$ Michael Kammen, Mystic Chords of Memory: The Transformation of Tradition in American Culture (New York: Alfred A. Knopf, 1991), 3. 
engage with the archival record, both within governmental, business, academic, and other institutional archives and within manuscript collecting repositories, they also manipulate the past, either deliberately or, far more often, subconsciously. As Tom Nesmith observes, "in description and reference, archivists ... significantly shape what counts as meaningful context. ... That is considerable power and one which can clearly influence readings by users of archives." ${ }^{97}$ For example, in conducting research on Indian women who cohabited with or married European men between 1760 and 1840, Durba Ghosh found that in India, "documents that spoke directly to my topic were difficult to find," and that in Britain, "ways of cataloging and listing the archive's contents" made her success "unlikely" since "most of the documents are ordered by and collected under categories like revenue, judicial, foreign, political-all matters that likely barely touched these women's lives." 98 Even basic practices based on provenance and original order can thus reflect hidden assumptions that skew archivists' approaches to the past, to the record. The solution to this is not to attempt to restore the lost innocence of archivists' neutrality, but to recognize their unavoidable influence on the process and to make their actions as transparent as possible. Although they do not always have the power or authority to overcome institutional or political barriers to action, archivists cannot-and should not-continue to pretend to be passive observers and handmaidens to history.

Archival description is inherently subjective. Archivists must constantly choose what facts are important and which are not as they create a narrative that will "guide" (note the implications of this archival terminology) researchers to the records. As Wendy Duff and Verne Harris warn, "what we choose to stress and what we choose to ignore is always and unavoidably subjective, and the value judgments that archivists make affect in turn how researchers find, perceive, and use records." As they conclude, "Description is always story telling-intertwining facts with narratives, observation with interpretation." 99 Archivists wield substantial power in these processes, and they must use it to achieve positive outcomes.

In preparing finding aids, archivists should be alert for subtle shadings of bias and privilege in how they refer to social groups and individuals. This is what Verne Harris identifies as "the politics of archival description." ${ }^{100}$ A "BiogHist

\footnotetext{
${ }^{97}$ Tom Nesmith, “Still Fuzzy, But More Accurate: Some Thoughts on the 'Ghosts' of Archival Theory," Archivaria 47 (Spring 1999): 144-45.

${ }^{98}$ Durba Ghosh, "National Narratives and the Politics of Miscegenation," in Archive Stories, 38.

${ }^{99}$ Wendy Duff and Verne Harris, "Stories and Names: Archival Description as Narrating Records and Constructing Meanings," Archival Science 2 (2002): 275-76.

${ }^{100}$ Harris, “ 'A World Whose Horizon Can Only Be Justice': Toward a Politics of Recordmaking," in Archives and Justice, 260.
} 
Note" that refers only to a records creator's professional career and not to his or her family and social relations may reflect the documented aspects of the person's life but not the context in which such actions took place. Subtle shadings of language-adjectives, adverbs, dependent clauses-can reflect archivists' own assumptions and biases. They may look with dismay at a previous generation's depiction of gays and lesbians with terms such as "social deviant" or worse; but what are their own cultural blinders? In a revealing analysis of archival finding aids produced between the 1930s and the present, Rainbow Koehl found telling examples of value-laden terms being used with little apparent awareness of the cultural meanings and interpretations they embody. The finding aid for records of a state department of civil defense, for example, indicates that the files contained information about national security, civil defense activities, and "fringe" areas such as antinuclear protests, unidentified flying objects, and other topics. Using a term such as fringe to marginalize certain topics is a political act. The same finding aid states that the records reflect activities associated with the "Cold War, Korean conflict, Berlin Crisis, Cuban Crisis, Vietnam War, [and] the civil disturbances of the 1960s and 1970s." As Koehl points out, "To call one event a war and another conflict is quite different. .. .When the archivist uses the phrase 'civil disturbances' it also minimizes the protests that occurred across the nation against the Vietnam War as well as the protests of the civil rights movement." ${ }^{101}$ In other finding aids, Koehl finds references to Mexican "bandits," "Spanish-American War Hero," and similar value-laden terms. Koehl explains: "Single words carry much more than their denotations: they also carry connotations that are usually heavily culturally bound."102 Archivists need to examine their own professional assumptions and procedures to avoid perpetuating status quo power relations through archival operations.

In reference and access services, do archivists permit the freest possible use of their records, or do they limit access to "serious researchers" or "scholars"? Do they provide the same level of research assistance to genealogists and local historians as they do to academics or published authors? Professional archivists have, for the most part, abandoned discriminatory past practices, but sometimes reference practices do not meet professional standards. Just as archivists insert their own values into the creation of finding aids and indexes, usually without even realizing it, so too do they intrude into the reference process. Archivists decide which subjects are of prime importance, Koehl contends:

Researchers, of course, may peruse the records themselves and come to their own conclusions. However, when archivists have compiled summaries and

${ }^{101}$ Rainbow L. Koehl, "What Lies Beneath: How Description in Archival Finding Aids Mirrors Our Society's Values: A Case Study of Four Repositories" (master's thesis, Western Washington University, 2006), 56-58.

${ }^{102}$ Koehl, "What Lies Beneath," 62. 
index terms for researchers it invites the researchers to be lazy in their work and rely wholly on the information provided for them without questioning its omniscience and exploring the documents on their own. Again, the danger is that rarely do they appear to realize that they are passively relinquishing the power to interpret history to archivists. ${ }^{103}$

One example of this, in my own experience, came in 1975 from a fellow graduate student conducting archival research. He found that a prominent historian had used a quotation from a plantation mistress, found in the finding aid for her diary and other papers, stating that Southern women hated slavery because bondage reminded them of their dependence on husbands. In reading the entire diary, covering more than thirty years, he found that this was the only comment that even remotely suggested such an opinion. The prominent historian erred by reading the finding aid and not the entire diary. Even worse, this quotation became the basis for an inaccurate interpretation in a widely read book. Clearly, these were the actions of a lazy researcher, but they caution archivists that highlighting some information privileges one perspective on the past, which can distort the meaning of archival records.

\section{Professional Responsibility and Social Justice}

These initiatives will be easier to undertake for archivists in collecting repositories, where they can more readily adapt collecting policies and goals to reflect an inclusive approach to documenting society. However, even archivists in institutional archives can effect some changes. Ensuring the protection of records required for legal accountability should be both a policy and a goal for all institutional archives and records programs. Institutional archivists could also consider retention and appraisal policies to ensure that records and documentation are preserved for all people affected by institutional activities, including workers, clients, and consumers as well as executives and stockholders. Finding aids can be prepared considering all potential future users, and careful consideration can be given to terminology used and assumptions made about how records and records creators are described. Such changes would not require major alterations in the mission or policies of an institutional archives, nor would it be necessary to endanger institutional support or funding for archives and records management.

On the broader level of professional practice, archivists and records managers need to commit themselves and their profession to the requirements of accountability and social justice. One starting point should be to put their collective imaginations and wills behind SAA's commitment to diversity. As one

${ }^{103}$ Koehl, "What Lies Beneath," 63. 
A R C H I VES F O R A L L : P R O F E S S I O N A L R E S P O N S I B I L I T Y A

of SAA's key strategic issues, this needs to be addressed fully and energetically. SAA's diversity initiatives have two broad goals:

1. To commit the profession to reflecting a diverse society and to giving voice to marginalized groups.

2. To increase professional membership among marginalized groups, so that the archival profession's membership will reflect the diversity within society.

Commitment to diversity and inclusiveness must have an international perspective to be effective. For example, the British Library has launched an Endangered Archives Program. According to its director, Graham Shaw, "The Program has two principal objectives: to contribute to the preservation of mankind's documentary heritage particularly in those less well-developed regions of the world where collections may be more at risk and where the availability of funding may be limited; and to help foster professional standards in cataloguing, preservation, etc. and so assist in safeguarding the longer term availability and accessibility of heritage collections worldwide." Shaw quotes the UNESCO Memory of the World initiative statement to explain the importance of such efforts: "Documentary heritage reflects the diversity of languages, peoples, and cultures. It is the mirror of the world and its memory, but this memory is fragile. Every day, irreplaceable parts of this memory disappear forever."104

Responding effectively to the challenges of using the power of archives for the public good will require a broad commitment by the archival profession to reflect on underlying assumptions and biases, and to overcome these through a renewed commitment to democratic values. There are risks involved in such changes. It will be difficult to commit archivists and their profession to a more inclusive view of social responsibilities. But the stakes are too high not to accept these challenges. Historical examples of abuses of power, control through manipulation of the archival record, and efforts to limit access to vital information show the dangers of misusing the power of archives and records. Let us commit ourselves to preventing the archival profession's explicit or implicit support of privileged elites and powerful rulers at the expense of the people's rights and interests. Let us commit ourselves to the values of public accountability, open government, cultural diversity, and social justice. Then we archivists can truly say that we are ensuring archives for all and employing our professional skills to promote a better society.

\footnotetext{
${ }^{104}$ Graham Shaw, presentation on the Endangered Archives Program, Yale Center for International and Area Studies Global Resources Network Conference, March 2005, available at http://www.library.yale.edu/mssa/globalrecord/new_web/ shaw.html\#text, accessed 11 May 2007.
} 